\title{
Note on the magnetostratigraphy of the Cretaceous deposits of SW Bornholm, Denmark
}

\author{
H. J. HANSEN and K. L. RASMUSSEN
}

\begin{abstract}
Hansen, H. J. \& Rasmussen, K. L.: Note on the magnetostratigraphy of the Cretaceous deposits of SW Bornholm, Denmark. Bull. geol. Soc. Denmark, vol. 38, pp. 227-229, Copenhagen, February 19th, 1991. https://doi.org/10.37570/bgsd-1990-38-24
Paleomagnetic investigations have been carried out on Arnager Greensand, Arnager Limestone, and Greensand.
The Arnager Greensand was found to belong to a magnetically normal period. The overlying Arnager Limestone was likewise found to belong to a normal period.
The Bavnodde Greensand was found to be normal except for the very youngest level exposed, which was found to belong to a reversed interval.
In view of the suggested biostratigraphical age of the Bavnodde Greensand (lower part of the Santo- nian) we interpret the reversed sediments as belonging eithel to magnetochrone 33 reversed or to a magnetic excursison.

H. J. Hansen, Geological Institute, University of Copenhagen, Øster Voldgade 10, DK-1350. K. L. Ras-mussen, Geohysical Institute, University of Copenhagen, Haraldsgade 6, DK-2200. December 16th, 1989.

\section{Introduction}

The age of the Cretaceous marine deposite outcropping on the SW coast of the island of Bornholm in the Baltic Sea has been a matter of some dispute (see Kennedy \& Christensen, this volume). Although the periods in question (Cenomanian-Santonian) could for the main part be expected to belong the Cretaceous long normal period, the deposits were nonetheless sampled for magnetostratigraphy.

\section{Materials and methods}

From the Arnager Greensand and Bavnodde Greensand samples were collected in $2.5 \mathrm{~cm}$ long and $2.5 \mathrm{~cm}$ diameter aluminium pipes that were sharpened to provide a cutting edge. Sampling was made from excavated terraces in the exposures. The sampling depth was ca. $20 \mathrm{~cm}$ below the exposed surface. The aluminium pipes with their content of sediment were wrapped in kitchen foil and later in the laboratory sealed with dentist wax. Samples from the Arnager Limestone were drilled in the laboratory by 2.5 $\mathrm{cm}$ water cooled drill pipes from larger oriented blocks.
The samples were AC-demagnetized following the procedure described in Hansen et al. (1989). Demagnetization in an alternating field of $150 \mathrm{Oe}$ left around $50 \%$ of the NRM and was accordingly applied to all samples. Thermal demagnetization was not attempted since the dentist wax has a very low melting point.

\section{Results}

The three levels sampled in the Arnager Greensand do not encompass the stratigraphically lowest level exposed, since the sediments in that part carry a rather high amount of redeposited phosphatic clasts. The remaining levels (the only available exposures) all gave results which we interpret as being of normal polarity (fig. 1).

In the Arnager Limestone only the large exposure plus one level higher has been sampled. The uppermost 3 meters of the coastal cliff were not sampled due to danger of falling blocks. All levels showed normal polarity (fig. 1).

The Bavnodde Greensand exposure contains at least one fault (Jensen and Hamann, 1989) so it was not possible to make continuous sampling. The available exposures were sampled and the four lowermost levels showed normal polarity, 


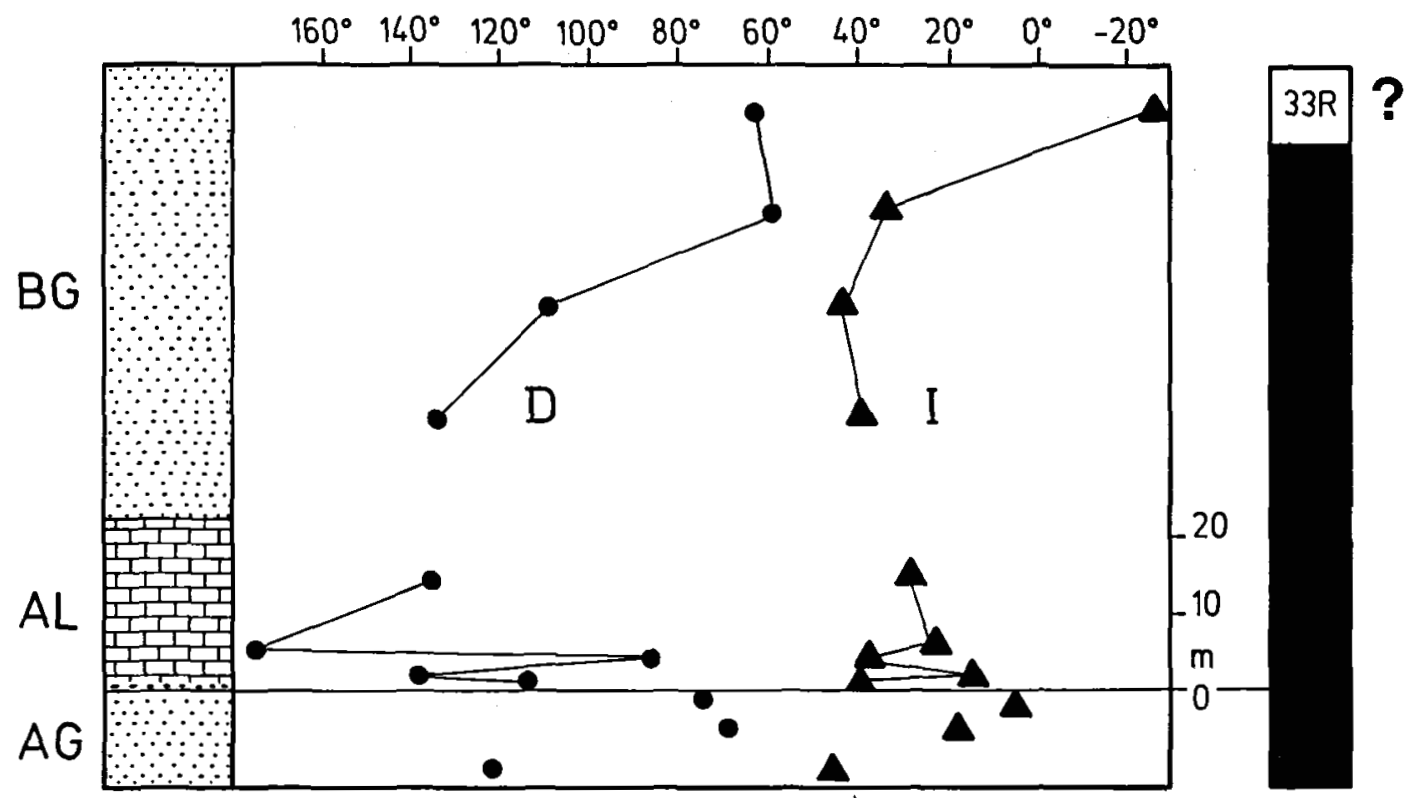

Fig. 1. Composite figure showing simplified lithologic column (AG: Arnager Greensand; AL: Arnager Limestone; BG: Bavnodde Greensand), VGP inclinations and declinations along with the paleomagnetic interpretation. The vertical scale is only valid for the samples from the Arnager Limestone and the topmost sample level in the Arnager Greensand. I: inclinations; D: declinations.

while the stratigraphically youngest part showed reversed polarity.

With reference to the various magnetostratigraphic scales (Ness et al. 1980; Channell and Medizza 1981; Lowrie and Alvarez 1981; Harland et al. 1982; Hallam et al. 1985) and the biostratigraphic placement of the Bavnodde Greensand in the lower part of the Santonian (Kennedy and Christensen this volume) we suggest that the topmost exposed part of the Bavnodde Greensand either belongs to the interval 33 $\mathrm{R}$ or represents an excursion. Ness et al. (1980) place reversed period 33 from about the middle of the Santonian to the lower part of the Campanian while the other authors place it in the lower Campanian. If the latter placement is correct, the reversed interval in the upper part of the Bavnodde Greensand must represent a magnetic excursion.

The Arnager Greensand and the Arnager Limestone both belong to the Cretaceous long normal period and cannot from the magnetostratigraphy be placed within this interval with any degree of certainty.

Acknowledgements. This study was supported by the Geological Central Institute, University of Copenhagen as well as the Danish Natural Science Research Council. The use of the field station on Bornholm is gratefully acknowledged.

\section{Dansk sammendrag}

Den paleomagnetiske stratigrafi i kystblotningerne af Arnager grønsand, Arnager kalk og Bavnodde grønsand er blevet undersøgt.

Arnager grønsandet og Arnager kalken tilhører normale magnetiske perioder, ligesom hovedparten af den blottede del af Bavnodde grønsandet. Det yngste blottede niveau i Bavnodde grønsandet viser imidlertid revers magnetisering.

I betragtning af den biostratigrafiske placering af Bavnodde grønsandet $i$ den nedre del af santonien, kan det reverse interval være den nedre del af magnetozone 33 revers (hvis man følger Ness et al. 1980). Dette vil medf $ø$ re en mellem santonien alder af det reverse interval. Hvis man imidlertid følger Hallam et al. (1985) må det reverse interval henføres til en magnetisk ekscursion.

\section{References}

Channell, J.E.T. \& Medizza, F. 1981: Upper Cretaceous and Palaeogene magnetic stratigraphy and biostratigraphy from the Venetian (Southern) Alps. Earth and Planetary Science Letters, 55, 419-432.

Hallam, A., Hancock, J. M., LaBrecque, J. L., Lowrie, W. \& Channell, J. E. T. 1985: Jurassic and Cretaceous geochronology and Jurassic to Paleogene magnetostratigraphy in Snelling, N.J. (ed.): The chronology of the geological tecord, 118-140, Mem. Geol. Sac. London no. 10.

Hansen, H.J., Gwozdz, R. \& Rasmussen, K. L. 1989: The continental Cretaceous-Tertiary boundary in the Aix-enProvence region, South France. A preliminary paleomagnetic study. Cahiers de la reserve geologique de Haute Provence 1, 43-50.

Harland, W. B., Cox, A.V., Llewellyn, P. G., Pickton, C. A. G., Smith, A.G. \& Walters, R. 1982: A geologic 
time scale. Cambridge University Press, Cambridge. $128 \mathrm{pp}$.

Jensen, J.B. \& Hamann, E. 1989: Geological mapping of Mesozoic deposits along the eastern margin of the Rønne Graben, offshore Bornholm, Denmark. Bull. geol. Soc. Denmark 37, 237-260.

Kennedy, W.J. \& Christensen, W. K. 1991: Coniacian and
Santonian ammonites from Bornholm, Denmark. Bull. geol. Soc. Denmark, 38, 203-226.

Ness, G., Levi, S. \& Couch, R. 1980: Marine magnetic anomaly timescales for the Cenozoic and Late Cretaceous: A prècis, critique and synthesis. Rev. Geophys. Space Phys. $18,753-770$. 